\title{
Open versus minimally invasive sacroiliac joint fusion: a multi-center comparison of perioperative measures and clinical outcomes
}

\author{
Arnold Graham Smith ${ }^{1}$, Robyn Capobianco ${ }^{2 *}$, Daniel Cher $^{2}$, Leonard Rudolf ${ }^{3}$, Donald Sachs ${ }^{4}$, Mukund Gundanna ${ }^{5}$,
} Jeffrey Kleiner ${ }^{6}$, Milan G Mody ${ }^{7}$ and A Nick Shamie ${ }^{8}$

\begin{abstract}
Background: Sacroiliac (SI) joint pain is an under diagnosed source of low back pain due in part to lack of visible pathology on radiographs and symptoms mimicking other back-related disorders. Open SI joint fusion has been performed since the 1920s. This technique has fallen out of favor with the introduction of minimally invasive options. To date there has been no direct comparison between open and MIS SI joint fusion.

Methods: We conducted a multi-center, retrospective comparative cohort study of patients who underwent SI joint fusion using either an open surgical (OS) technique using a combination of screws and cages or a minimally invasive surgical (MIS) technique with a series of titanium plasma spray (TPS) coated triangular implants. Operative measures including surgical operating time, length of hospitalization and estimated blood loss (EBL) were collected along with demographics and medical history, surgical complications, and 12- and 24-month pain scores. Improvements in pain were compared after matching for age and gender and controlling for a history of lumbar spine fusion using repeated measures analysis of variance.

Results: Data were available for 263 patients treated by 7 surgeons; 149 patients treated with OS and 114 treated with MIS SI joint fusion. Compared to OS patients, MIS patients were on average 10 years older (mean age 57 vs. 46) and $69 \%$ of all patients were female. MIS operative measures of EBL, operating time and length of hospitalization were significantly lower than open surgery $(p<0.001)$. Pain relief, measured as change from baseline to 12 months in VAS pain rating, was 3.5 points lower in the MIS vs. OS group $(-6.2$ vs. -2.7 points, $p<0.001)$. When matched for age, gender and a history of prior lumbar spinal fusion, postoperative pain scores were on average 3.0 points (95\% Cl 2.1 - 4.0) lower in MIS vs. OS (rANOVA $p<0.001$ ).

Conclusions: In this multi-center comparative study, patients who underwent either OS or MIS SI joint fusion showed postoperative improvements in pain score. Compared to OS patients, patients who underwent MIS SI joint fusion had significantly greater pain relief and more favorable perioperative surgical measures.
\end{abstract}

Keywords: Minimally invasive surgery, Sacroiliac joint, Arthrodesis, Open surgery

\section{Background}

Sacroiliac (SI) joint pain can be debilitating to patients, yet is an often-overlooked source of low back pain. Diagnosing the SI joint as the primary pain generator is difficult as patients often present with a combination of low back, groin, gluteal, and/or leg pain with signs mimicking radicular or discogenic distributions [1-3]. Furthermore,

\footnotetext{
* Correspondence: rcapobianco@si-bone.com

${ }^{2}$ SI-BONE, Inc., 3055 Olin Ave, Suite 2200, San Jose, CA, USA

Full list of author information is available at the end of the article
}

SI joint abnormalities may not be visible on imaging studies ordered to evaluate the lumbar spine.

The number of patients under-diagnosed and/or misdiagnosed is not inconsequential. Several studies report up to $30 \%$ prevalence of SI joint disorders in patients diagnosed with low back pain [2,4-6]. Disorders of the SI joint may be the result of trauma, pregnancy, inflammatory arthritis, osteoarthritis or degeneration of the joint either de novo or post lumbar spinal fusion [7]. SI joint pain after lumbar fusion is not uncommon. Two studies 
report prevalence rates of $40 \%$ and $43 \%$ [8,9]. Up to $75 \%$ of post-lumbar fusion patients develop significant radiographic SI joint degeneration after 5 years [10]. Diagnosis of SI joint disorders in the absence of acute trauma is made with a careful amalgamation of patient history, clinical exam, provocative physical tests, imaging, and diagnostic joint injections [11-14]. The treatment regimen often includes medication optimization, activity modification, physical therapy, therapeutic (i.e. steroid) joint injections and, in more severe cases, radiofrequency ablation [15]. For patients who do not experience adequate resolution of symptoms, surgical arthrodesis is an option.

Smith-Petersen and Rogers first reported SI joint arthrodesis in 1921 [16]. Studies that followed continued non-instrumented approaches to achieve arthrodesis and most required either long periods of immobilization or casting and bracing for a substantial period of time [17]. In the mid 1980s, reports of internal fixation using metal plates and screws began to appear [18-21]. Though casting and bracing were no longer required, perioperative morbidity was not trivial with relatively large incisions, significant bone harvesting, and lengthy hospital stays. Moreover, patients were kept non-weight bearing for several months postoperatively.

Reports of minimally invasive surgical (MIS) techniques to address the SI joint began appearing in 2008. However instrumentation remained limited to threaded screws and cages that rely on autologous bone graft [22-24]. Recently, there have been several reports of an MIS technique involving placing a series of triangular titanium implants across the SI joint (iFuse ${ }^{\circledast}$ Implant System, SI-BONE, Inc. San Jose, CA) with promising outcomes [25-29]. The design of this implant provides an interference fit into bone and the porous titanium plasma spray (TPS) coating on the surface allows for biological fixation. The confluence of these attributes renders the use of additional bone grafting material unnecessary.

According to a recent survey of spine surgeons, use of the MIS approach to fuse the SI joint has recently increased in popularity compared to traditional open fusion of the SI joint; in 2012, 85\% of SI joint fusion was performed using minimally invasive techniques [30]. However, there have been no direct or indirect comparisons of these surgical methods. The purpose of this study is to compare operative measures, safety, and effectiveness between open surgical and minimally invasive SI joint fusion methods using a series of triangular titanium, porous TPS coated implants (iFuse Implant System, SI-BONE, Inc., San Jose, CA).

\section{Methods}

A retrospective multi-center comparative study was undertaken after Institutional Review Board approval was obtained. Seven (7) surgeon sites participated; 3 surgeons who perform open SIJ fusion surgery (AGS, JK, MGM) and 4 who perform MIS SIJ fusion using triangular, titanium, TPS coated implants (LR, DS, MG, NS). A total of 263 patients were identified who underwent SIJ fusion surgery and had both pre-operative and 12- and/or 24-month postoperative pain scales documented in the medical chart; 149 in the open surgical technique cohort and 114 in the MIS technique cohort. Patients were treated between 1994 and 2012. Data extracted from the medical chart included demographics, history of prior lumbar spinal fusion, length of hospital stay (LOS), surgical operating time, estimated blood loss (EBL), complications of surgery and clinical outcomes using a 0-10 visual analog scale (VAS). Descriptive statistics are summarized as mean and standard deviation for continuous variables, and frequency charts for categorical variables.

\section{Diagnosis}

All patients were diagnosed with SI joint disorders using a combination of detailed history, clinical exam, imaging and diagnostic injections. A positive result on 3 or more pain provocation tests such as Gaenslen's, flexion abduction external rotation (FABER), compression, distraction and thigh thrust, was used as criteria for further testing to confirm the SI joint as the primary pain generator $[11,31]$. Diagnostic imaging studies such as $\mathrm{x}$-ray, CT and MRI were performed on all patients to assess pathology in the lumbopelvic hip complex for differential diagnosis. Image-guided intraarticular anesthetic injections were performed as a final step to confirm the diagnosis. All patients had failed a 6-month course of non-surgical treatment consisting of a combination of medication optimization, activity modification, physical therapy and SI joint injections before they were offered surgery.

\section{Open technique overview}

Several techniques for open fusion of the SI joint have been reported [7,20,21,24]. However, open SI joint surgery technique varied minimally between sites participating in this study. These variations are described where applicable. All sites in this study performed an open posterior approach to the SI joint. After the administration of general endotracheal anesthesia, the patient was placed prone on a radiolucent table, wired for electromyography, and prepped in the normal sterile fashion. A longitudinal incision was made centered over the posterior-superior iliac spine and deepened to expose the bone. Retractors were used to pull back the soft tissue and expose the posterior portion of the inferior SI joint. An osteotome was used to remove the portion of the posterior iliac crest that overhangs the SI joint. This bone was morselized and was later used as graft. Curettes and rongeurs were used to remove the cartilage from the articular portion of the joint 
and the interosseous ligament from the fibrous portion of the SI joint. One or two holes to accommodate cages were drilled into the SI joint and enlarged with a reamer. The cage(s) were packed with morselized bone and/or rhBMP (off label for this indication) and placed into position under fluoroscopic guidance. Additional bone material was then packed into the remaining open parts of the SI joint. Two $6.5 \times 40 \mathrm{~mm}$ cancellous iliosacral lag screws were then placed in standard fashion. Under fluoroscopic guidance, pins were placed from lateral to medial across the ilium, across the SI joint and into the sacrum. The pins were then over drilled with a cannulated drill. The holes were tapped with a $6.5 \mathrm{~mm}$ tap and the screws with large washers were placed. At one site (AGS), the fixation consisted of a $6.5 \mathrm{~mm}$ pedicle screw placed into the S1 pedicle and a second $6.5 \mathrm{~mm}$ pedicle screw placed between the inner and outer tables of the ilium. A $3 \mathrm{~cm}$ spinal rod was then used to connect the two screws. As for the fixation, one surgeon (MGM) used recon plating across the SI joint with placed 2 cancellous screws placed in both the sacral ala and the ilium, as well as one long percutaneous cannulated screws across the SI joint. For all surgeons, EMG stimulation was used throughout the procedure to ensure safe placement of instrumentation. The wound was then irrigated, a hemovac drain was placed between the deep and superficial fascia, and the tissue layers were closed sequentially.

\section{MIS technique overview}

Minimally invasive SI joint surgery using a series of triangular, titanium, TPS coated implants (iFuse Implant System) (Figure 1) was performed with the patient on a radiolucent table to facilitate the use of intraoperative fluoroscopy. After general endotracheal anesthesia was administered, the patient was turned prone and prepped in the normal sterile fashion. A lateral incision $(3 \mathrm{~cm})$ was made into the gluteal region, positioned over the sacral body as viewed on a lateral fluoroscopic image. The fascia was then bluntly dissected to reach the outer table of the ilium. A Steinmann pin was passed through the ilium across the SI joint to the center of the sacrum (lateral to the neural foramen). After a soft tissue protector was passed over the pin, a hand drill was used to create a pathway across the ilium, across the SI joint and into the sacrum. Finally, a triangular broach was used to further decorticate the bone and prepare a triangular channel to receive the first implant. Using a pin guidance system, a total of three implants were placed. The most cephalad implant was seated within the sacral ala above the first neural foramen. The second implant was located above or adjacent to the S1 foramen and the third between the S1 and S2 foramen (Figure 2). The incision was irrigated and the tissue layers were closed. A variable program of

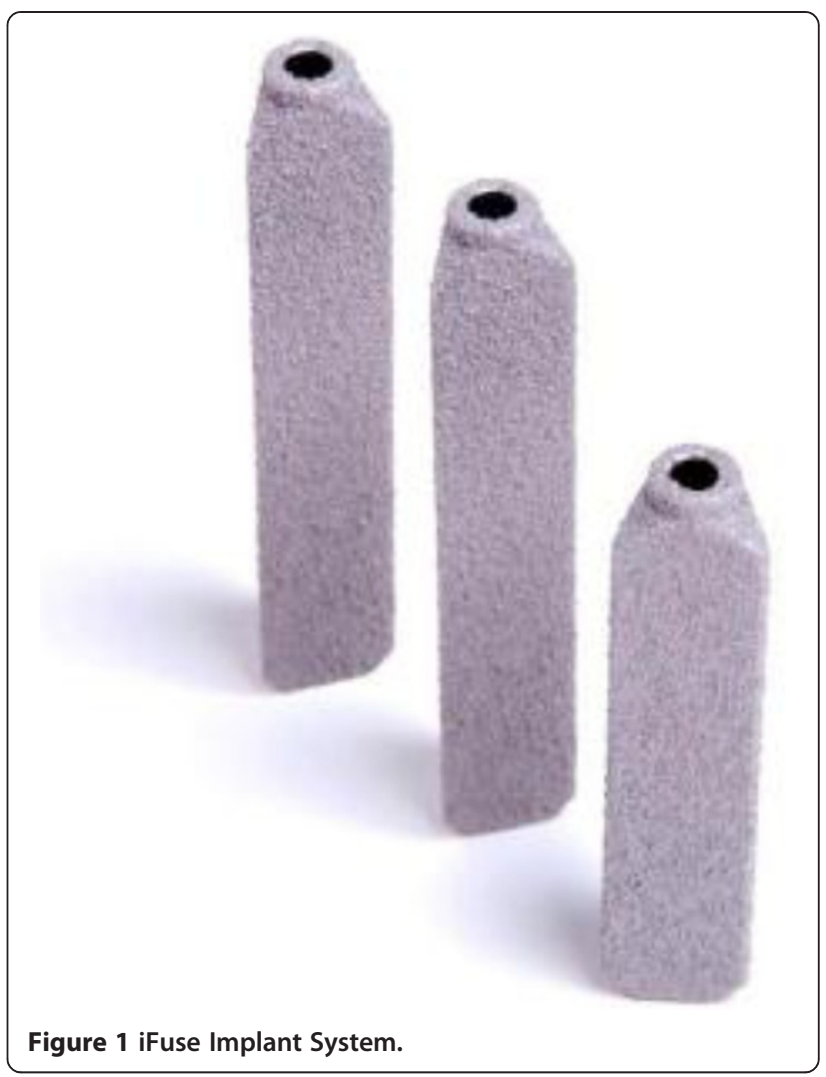

gradual return to full weight bearing was employed based on local practices and patient needs. In general, patients were instructed to ambulate partial weight bearing with the assistance of a walker for the first 3 weeks after which time toe touch ambulation was recommended for another 4 weeks. After a regimen of




gradual return to full weight bearing, patients began 4 weeks of physical therapy.

\section{Clinical outcome assessments}

Patient reported clinical outcomes were collected prospectively prior to surgery to establish baseline values and at follow up intervals per each surgeon's routine practice. For consistency in reporting, pain scores using visual analog scale (VAS) were collected at visits close to 12 and 24 months only.

Clinical improvement was defined using minimum clinically important difference (MCID) and substantial clinical benefit (SCB) values available in the literature. As there are currently no reported MCID or SCB values for SI joint fusion, values were chosen using lumbar spine criteria published by Copay et al. for MCID and Glassman et al. for SCB [32,33]. MCID for pain is defined as a change of $>2.0$ pts and SCB is defined as a 2.5-point decrease or raw score of $<3.5$.

\section{Statistical analysis}

Baseline demographic variables were summarized with mean, standard deviation and frequency tables. Demographic characteristics were compared across cohorts using $\mathrm{t}$ tests for continuous variables and chi-squared tests for nominal variables. Surgical parameters (e.g., operating time, estimated blood loss, length of stay) were compared using t tests.

A key outcome variable was the change in pain scores on VAS. Mean baseline VAS scores, as well as mean change from baseline at 12 and 24 months, were tabulated. To account for potential differences in patient characteristics across cohorts, VAS pain scores were compared after matching, as follows. Patients in the two treatment groups were matched based on gender and age in 5-year intervals (20-25 years, 25-30 years, etc.). This process led to a variable $\mathrm{m}: \mathrm{n}$ matching where $\mathrm{m} \neq$ $\mathrm{n}$. Variable matching was due in part to missing values of the pain score as well as differences in overall age distribution between the two cohorts.

A linear mixed effects model (SAS PROC MIXED) was used to estimate treatment differences using a cell means formulation with additional covariates of prior lumbar fusion and a random effect for patient. Prior lumbar fusion was included as a covariate since it may increase the risk of SI joint degeneration, and also reflects a history of serious back pain requiring surgery. The cell means formulation has a parameter for each treatment, each block (i.e., gender and 5-year age category), visit, and a random effect for patient. Pairwise differences between treatments for blocks of matched age-category/gender were estimated. Sparse combinations of age/gender blocks that resulted in inability of the model to provide estimates were removed from the
Table 1 Patient demographics

\begin{tabular}{llll}
\hline & $\begin{array}{l}\text { Open surgical } \\
\text { fusion }\end{array}$ & $\begin{array}{l}\text { Minimally invasive } \\
\text { fusion }\end{array}$ & P-value \\
\hline $\mathrm{N}$ & 149 & 114 & - \\
Age, mean (SD) & $45.8(11.3)$ & $57.4(14.0)$ & $<.0001$ \\
Female, n (\%) & $103(69.1 \%)$ & $82(71.9 \%)$ & 0.6220 \\
$\begin{array}{l}\text { Prior lumbar spine } \\
\text { surgery, n (\%) }\end{array}$ & $35(23.5 \%)$ & $54(47.4 \%)$ & $<.0001$ \\
Side treated & & & \\
\multicolumn{1}{c}{ Left } & $74(49.7 \%)$ & $41(36.0 \%)$ & 0.0120 \\
\multicolumn{1}{c}{ Right } & $71(47.7 \%)$ & $62(54.4 \%)$ & \\
Both & $4(2.7 \%)$ & $11(9.6 \%)$ & \\
\hline
\end{tabular}

model. The final model was estimable and converged. A final treatment effect estimate was calculated by averaging over matched age-category/gender/treatment combinations. Analysis was performed using SAS 9.0 (Cary, $\mathrm{NC}$ ).

\section{Results}

A total of 263 patients were identified; 149 patients treated with open surgery (OS) and 114 patients who underwent minimally invasive surgery (MIS). Demographic characteristics of patients are shown in Table 1. Patients undergoing open surgical fusion were younger (mean age 45.8 vs. 57.4 years) and were less likely to have had prior lumbar fusion $(23.5 \%$ vs. $47.4 \%)$. Approximately $70 \%$ of all patients, regardless of surgery type, were women. Bilateral surgery was more common in those undergoing minimally invasive SI joint fusion.

Peri-operative measures were overall lower in the MIS group (Table 2). Open surgical fusion was a longer surgery, requiring an average $( \pm \mathrm{SD}) 163 \pm 25$ minutes compared to MIS fusion, which took just over an hour (mean $70 \pm 24$ minutes). Although blood loss estimates were available in only $60 \%$ of MIS patients, mean estimated blood loss was approximately one-eighth that of open SI joint fusion $(288 \pm 182 \mathrm{cc}$ in OS, $33 \pm 27 \mathrm{cc}$ in MIS). Most patients who undergo MIS SI joint fusion stay in the hospital overnight or are discharged the same day. Hospital length of stay, available from only 1 surgeon in the MIS cohort (MG) and all patients in the open cohort, was substantially shorter in the MIS group

Table 2 Operative Measures

\begin{tabular}{|c|c|c|c|c|c|}
\hline & \multirow{2}{*}{\multicolumn{2}{|c|}{$\frac{\text { Open surgical }}{\text { Fusion }}$}} & \multirow{2}{*}{\multicolumn{2}{|c|}{$\frac{\text { Minimally invasive }}{\text { Fusion }}$}} & \multirow[t]{2}{*}{ P-value } \\
\hline & & & & & \\
\hline & $\mathrm{N}$ & Mean (SD) & $\mathrm{N}$ & Mean (SD) & \\
\hline Operating room time & 100 & $163(25)$ & 63 & $70(24)$ & $<.0001$ \\
\hline Estimated blood loss & 138 & $288(182)$ & 66 & $33(27)$ & $<.0001$ \\
\hline Hospital length of stay & 137 & $5.1(1.9)$ & 30 & $1.3(0.5)$ & $<.0001$ \\
\hline
\end{tabular}


Table $3 \mathrm{SI}$ joint pain ratings at baseline and at 12- and 24-months postoperatively

\begin{tabular}{|c|c|c|c|c|}
\hline & \multirow{2}{*}{\multicolumn{2}{|c|}{$\begin{array}{c}\text { Open surgical } \\
\text { Fusion }\end{array}$}} & \multirow{2}{*}{\multicolumn{2}{|c|}{$\frac{\text { Minimally invasive }}{\text { Fusion }}$}} \\
\hline & & & & \\
\hline & $\mathrm{N}$ & $\begin{array}{l}\text { Mean (SD) } \\
\text { or } \%\end{array}$ & $\mathrm{~N}$ & $\begin{array}{l}\text { Mean (SD) } \\
\text { or \% }\end{array}$ \\
\hline VAS pain score at baseline & 139 & $7.1(1.9)$ & 113 & $8.3(1.6)$ \\
\hline $\begin{array}{l}\text { VAS pain score at } \\
12 \text { months }\end{array}$ & 114 & $4.6(3.0)$ & 94 & $2.3(2.6)$ \\
\hline VAS pain score at 24 months & 58 & $5.6(2.9)$ & 38 & $1.7(2.9)$ \\
\hline $\begin{array}{l}\text { Change in VAS pain score } \\
\text { at } 12 \text { months }\end{array}$ & 113 & $-2.7(3.2)$ & 93 & $-6.2(3.1)$ \\
\hline $\begin{array}{l}\text { Change in VAS pain score } \\
\text { at } 24 \text { months }\end{array}$ & 58 & $-2.0(3.3)$ & 38 & $-5.6(3.5)$ \\
\hline
\end{tabular}

(mean 1.3 days) compared to the OS group (mean 5.1 days).

Mean baseline VAS pain scores were just over 1 point higher in the MIS vs. open groups (8.3 vs. 7.1, p <.0001) (Table 3). At follow-up, the raw improvements from baseline in VAS pain scores were 3.6 and 3.7 points lower in the MIS group compared to the open group at 12 and 24 months after surgery, respectively. Using age and gender-matched blocks, repeated measures analysis of variance that also controlled for a history of prior lumbar fusion showed that the adjusted mean VAS pain scores during follow-up were 3.02 points lower in MIS vs. open ( $\mathrm{p}<.0001,95 \%$ CI $2.07-3.99$ points). The proportions of subjects showing a 2 or greater point decrease in pain scores at follow-up compared to baseline were $86 \%$ and $82 \%$ in the MIS group at 12 and 24 months, respectively, vs. $61 \%$ and $50 \%$ in the open group at 12 and 24 months (Table 4). Substantial clinical benefit was reached for $58 \%$ and $47 \%$ of patients in the open fusion group at 12 and 24 months, respectively. The percentage of patients reaching SCB in the MIS group was higher at $86 \%$ and $82 \%$ (Table 3). Decreases in pain scores were larger in the MIS group compared to the open group amongst patients either with or without a history of prior lumbar fusion, a known risk factor for SI joint degeneration (Table 5). A small number of patients underwent bilateral SI joint fusion (OS 4 cases,
MIS 11 cases); a comparison of clinical outcomes between these groups could not be performed due to the small sample sizes.

\section{Complications}

No intraoperative complications occurred. Postoperative complications were slightly more common in the open surgery group (21\% of patients) compared to the MIS group (18\%) (Table 6). The most common complications reported in both groups were postoperative neuropathy and transient trochanteric bursitis (4 OS and 2 MIS). In the OS group, leg pain (3), neuropathy (4) and wound related issues (6) were more common. In the MIS group, falls (4) and facet pain (4) were more frequent.

Forty-four percent $(66 / 149)$ of patients in the open surgery cohort subsequently underwent removal of spinal implants. In most cases, removal was for pain at the ilial or sacral screw. In contrast, only $3.5 \%$ of patients (4/114) undergoing MIS surgery underwent postoperative repositioning of the implants. In 3 patients, reoperation was due to nerve root impingement discovered on the postoperative CT scan. In one case, reoperation was performed at the surgeon's discretion based on radiographic findings only.

\section{Discussion}

Confidently diagnosing the SI joint as a pain generator is a challenging endeavor as symptoms may mimic other conditions such as lumbar and hip pathology. A history of sleep disturbance, pain on prolonged sitting and leg instability, pain in the low back, buttock, hip and groin as well as the SI joint are common. Furthermore, imaging studies ordered to evaluate low back or hip pain typically do not include a clear view of the SI joint. Unless educated to examine the SI joint, an improper diagnosis may be made. An accurate diagnosis requires a combination of history, physical examination maneuvers that stress the SI joint, and image-guided diagnostic injections into the joint.

Multiple surgical and non-surgical treatments for SI joint disorders are available. When non-surgical management fails to provide adequate relief of symptoms, surgical stabilization is an option. Published case series of various arthrodesis techniques report variable improvements in

Table 4 Improvements in SI joint pain at 12- and 24- months post-operatively

\begin{tabular}{|c|c|c|c|c|}
\hline \multirow[b]{3}{*}{ Change Category } & \multicolumn{2}{|c|}{ Open surgical } & \multicolumn{2}{|c|}{ Minimally invasive } \\
\hline & \multicolumn{2}{|c|}{ Fusion } & \multicolumn{2}{|c|}{ Fusion } \\
\hline & $12 \mathrm{Mo}$ & 24 Mo & 12 Mo & 24 Mo \\
\hline Improvement of at least 2 points & $69(61.1 \%)$ & $29(50.0 \%)$ & $80(86.0 \%)$ & $31(81.6 \%)$ \\
\hline Improvement of $<2$ points & $17(15.0 \%)$ & $7(12.1 \%)$ & $6(6.5 \%)$ & $1(2.6 \%)$ \\
\hline No change or worsening & $27(23.9 \%)$ & $22(37.9 \%)$ & $7(7.5 \%)$ & $6(15.8 \%)$ \\
\hline Improvement of at least 2.5 points or postoperative score $<3.5$ points & $66 / 114(58 \%)$ & $27 / 58(47 \%)$ & $81 / 94(86 \%)$ & $31 / 38(82 \%)$ \\
\hline
\end{tabular}


Table $\mathbf{5}$ SI joint pain ratings by history of prior lumbar spinal fusion

\begin{tabular}{|c|c|c|c|c|c|c|c|c|}
\hline & \multicolumn{4}{|c|}{ Open surgical fusion } & \multicolumn{4}{|c|}{ Minimally invasive fusion } \\
\hline & \multicolumn{4}{|c|}{ Prior lumbar fusion } & \multicolumn{4}{|c|}{ Prior lumbar fusion } \\
\hline & \multicolumn{2}{|r|}{ Yes } & \multicolumn{2}{|r|}{ No } & \multicolumn{2}{|r|}{ Yes } & \multicolumn{2}{|r|}{ No } \\
\hline & $\mathrm{N}$ & Mean (SD) & $\mathrm{N}$ & Mean (SD) & $\mathrm{N}$ & Mean (SD) & $\mathrm{N}$ & Mean (SD) \\
\hline VAS pain score at baseline & 33 & $7.0(1.7)$ & 106 & $7.2(1.9)$ & 53 & $8.5(1.3)$ & 60 & $8.1(1.9)$ \\
\hline VAS pain score at 12 months & 30 & $5.4(3.0)$ & 84 & $4.4(2.9)$ & 51 & $3.0(2.9)$ & 43 & $1.5(1.9)$ \\
\hline VAS pain score at 24 months & 10 & $6.7(2.0)$ & 48 & $5.4(3.1)$ & 17 & $1.9(3.2)$ & 21 & $1.5(2.6)$ \\
\hline Change in VAS pain score at 12 months & 29 & $-1.8(3.1)$ & 84 & $-3.0(3.2)$ & 50 & $-5.5(3.2)$ & 43 & $-7.0(2.8)$ \\
\hline Change in VAS pain score at 24 months & 10 & $-1.5(1.9)$ & 48 & $-2.1(3.5)$ & 17 & $-6.0(3.7)$ & 21 & $-5.2(3.4)$ \\
\hline
\end{tabular}

pain and function with more invasive approaches reporting moderately high complications and non-unions (Table 7) [17,19-24,26,27,29,34,35]. MIS techniques that use internal fixation, such as cages, plates and screws, often rely on bone graft harvesting, which may negatively affect outcomes.

Pain and degeneration of the SI joint after lumbar spinal fusion are common occurrences, with up to $43 \%$ of these

Table 6 Postoperative adverse events

\begin{tabular}{lll}
\hline Adverse events & OS & MIS \\
\hline Bone fragment near upper sacral screw causing pain & 1 & 0 \\
Buttock hematoma & 0 & 2 \\
Cellulitis & 1 & 3 \\
Deep venous thrombosis & 1 & 0 \\
Facet pain & 0 & 4 \\
Fall & 2 & 4 \\
Hip pain requiring spinal cord stimulator & 1 & 0 \\
lliotibial band pain & 2 & 0 \\
Leg pain & 3 & 0 \\
Lipoma in wound scar requiring surgical removal & 1 & 0 \\
Low back pain & 0 & 1 \\
Painful heterotopic ossification & 2 & 0 \\
Piriformis syndrome & 0 & 2 \\
Pneumothorax & 1 & 0 \\
Postoperative neuropathy & 4 & 0 \\
Pulmonary embolism & 2 & 0 \\
Scar pain requiring block & 3 \\
Screw loosening & 1 & 0 \\
Screw replacement misplacement & 3 & 1 \\
Strained buttock muscle & 1 & 0 \\
Trochanteric bursitis & 1 & 0 \\
Wound dehiscence & 0 & 1 \\
Wound infection & 4 & 2 \\
Wound seroma & 1 & 0 \\
Total & 34 & 20 \\
\hline
\end{tabular}

patients experiencing SI joint pain and $75 \%$ showing radiographic changes [6-8]. Open surgical techniques, whether using a posterior or anterior approach, show that these patients experience poorer outcomes [7]. Mason et al. found outcomes in patients treated with prior lumbar fusion to be significantly diminished after MIS SI joint fusion using hollow modular anchorage screws [36]. In contrast, three studies that report no difference in outcomes for patients with and without prior lumbar fusion using the MIS technique reported herein [26,28,29].

To our knowledge, this is the first multi-center comparison of open and MIS SI joint fusion surgery. Rigorous statistical methods (age- and gender-matching as well as controlling for a history of prior lumbar fusion) were employed in an attempt to account for patient characteristics that could affect outcomes after SI joint surgery. Results of this study illustrate the advantages expected of MIS spinal surgery: reduced surgically induced tissue damage, blood loss and surgical morbidity, and length of hospitalization. These parameters have been implicated as risk factors for surgical site infections [37-39]. Additionally, patients treated with MIS SI joint fusion experienced significantly greater improvements in pain than those who underwent open surgery, regardless of history of prior lumbar spinal fusion. The triangular shape, interference fit and TPS coating of the MIS implant allows for both immediate stabilization and long-term biological fixation of the device. Pseudoarthrosis, screw loosening, and spinal implant irritation were sources of surgical revisions (43\%) in the open surgery cohort. None of these complications were present in the MIS cohort. Revisions (3.5\%) in the MIS group were the result of suboptimal implant placement.

This study is not without limitations. First and foremost, it is not a randomized prospective trial. As discussed by McAfee et al., randomizing patients is extremely challenging in today's postmarket environment [40]. Many patients are unwilling to be randomized to a more invasive surgical procedure when a newer minimally invasive technique procedure is available without participating in such a clinical trial. Such trials have 
Table 7 Reports of SI joint fusion

\begin{tabular}{|c|c|c|c|c|c|c|}
\hline Author, Year & $\mathrm{N}$ & Demographics & Diagnostic Standard & $\begin{array}{l}\text { Surgical Procedure/Post-op } \\
\text { care }\end{array}$ & Results & Complications \\
\hline \multirow[t]{4}{*}{ Rudolf, 2012 [27] } & \multirow[t]{4}{*}{50} & Age: 54 & 3 or more positive & \multirow[t]{4}{*}{ iFuse Implant System } & OR time: $65+/-26 \mathrm{~min}$ & Superficial cellulitis: 3 \\
\hline & & Gender: 34 F/16 M & $\begin{array}{l}\text { provocative maneuvers, } \\
\text { confirmatory joint }\end{array}$ & & $\begin{array}{l}\text { Mean improvement on VAS: } \\
-4.3 \text { pts at } 12 \text { months }\end{array}$ & $\begin{array}{l}\text { Deep wound } \\
\text { infection:1 }\end{array}$ \\
\hline & & \multirow[t]{2}{*}{ Prior lumbar fusion: $44 \%$} & \multirow[t]{2}{*}{ injections } & & \multirow{2}{*}{$\begin{array}{l}\text { Satisfaction } 82 \% \text { at } \\
12 \text { months }\end{array}$} & Hematoma: 2 \\
\hline & & & & & & Reoperation: 3 \\
\hline \multirow[t]{4}{*}{ Sachs, 2013 [26] } & \multirow[t]{4}{*}{40} & Age: 58 & \multirow{4}{*}{$\begin{array}{l}3 \text { or more positive } \\
\text { provocative maneuvers, } \\
\text { confirmatory joint injections }\end{array}$} & \multirow[t]{4}{*}{ iFuse Implant System } & $\begin{array}{l}\text { Mean improvement on VAS } \\
\text { of }-7.8 \text { pts }(p<0.001)\end{array}$ & Piriformis syndrome:1 \\
\hline & & Gender: $30 \mathrm{~F} / 10 \mathrm{M}$ & & & Patient satisfaction: & New LBP:1 \\
\hline & & Follow up: 12 months & & & & Facet joint pain: 8 \\
\hline & & Prior lumbar fusion: $30 \%$ & & & & Trochanteric bursitis: 2 \\
\hline \multirow[t]{8}{*}{ Cummings, 2013 [29] } & \multirow[t]{8}{*}{18} & Age: 64 & \multirow{8}{*}{$\begin{array}{l}3 \text { or more positive } \\
\text { provocative maneuvers, } \\
\text { confirmatory joint injections }\end{array}$} & \multirow[t]{8}{*}{ iFuse Implant System } & $\begin{array}{l}\text { Mean improvement in clinical } \\
\text { outcomes: }\end{array}$ & Trochanteric bursitis 3 \\
\hline & & Gender: 12 F/6 M & & & VAS -6.6pts, & Hematoma 1 \\
\hline & & Prior lumbar fusion: 61\% & & & ODI $-37.5 p t s$ & Fluid retention \\
\hline & & & & & SF-12PCS 11.2, & 1 \\
\hline & & & & & SF-12 MCS 20.4 & Toe numbness 1 \\
\hline & & & & & Satisfaction: & implant malposition 1 \\
\hline & & & & & Very 55.6\%, Somewhat 39\%. & \\
\hline & & & & & $\begin{array}{l}\text { Would have surgery again: } \\
\text { yes } 83 \% \text {, likely } 6 \%\end{array}$ & \\
\hline \multirow[t]{7}{*}{ Kibsgard, 2012 [34] } & \multirow[t]{7}{*}{50,28} & Fusion (50 pts) & \multirow[t]{7}{*}{$\begin{array}{l}\text { PSIS tenderness, positive } \\
\text { straight leg raise, positive } \\
\text { provocative maneuvers }\end{array}$} & $\begin{array}{l}\text { Trans-iliac fusion or intra/ } \\
\text { extra-articular fusion between } \\
\text { the ilium and the sacrum } \\
\text { using cortical iliac window } \\
\text { and iliac crest autograft. }\end{array}$ & $\begin{array}{l}\text { Surgical patients after } 1 \text { year: } \\
24(48 \%) \text { patients were good, } \\
12(24 \%) \text { were fair, and } 14 \\
(28 \%) \text { were poor. }\end{array}$ & Reoperation: 7 \\
\hline & & Age: 58 & & \multirow{6}{*}{$\begin{array}{l}\text { Post-op care: In most cases } \\
\text { the patients were confined to } \\
6 \text { weeks of bed rest. }\end{array}$} & \multirow{6}{*}{$\begin{array}{l}\text { No significant difference in } \\
\text { ODI, VAS, or SF-36 between } \\
\text { surgery and non-surgery pa- } \\
\text { tients after long-term follow- } \\
\text { up. }\end{array}$} & Nonunion: 8 \\
\hline & & Gender: 47 F/3 M & & & & Jaundice: 1 \\
\hline & & Follow-up: 23 yrs & & & & $\begin{array}{l}\text { Pulmonary embolism: } \\
1\end{array}$ \\
\hline & & Unilateral 21/Bilateral 25 & & & & Pin tract infection: 1 \\
\hline & & $\begin{array}{l}\text { Dx: Post-partum (30), } \\
\text { Trauma (8), Idiopathic (12) }\end{array}$ & & & & $\begin{array}{l}\text { Complication rate: } \\
20 \%\end{array}$ \\
\hline & & Non-Surgery (28 pts) & & & & Revision rate: $14 \%$ \\
\hline
\end{tabular}

Age: 52

Gender: $28 \mathrm{~F}$

Follow-up: 17 yrs 
Table 7 Reports of SI joint fusion (Continued)

\begin{tabular}{|c|c|c|c|c|c|c|}
\hline \multirow[t]{6}{*}{ Khurana, 2009 [22] } & \multirow[t]{6}{*}{15} & Age: 48.7 years & \multirow[t]{6}{*}{$\begin{array}{l}\text { Tenderness over the posterior } \\
\text { SI joint, positive provocative } \\
\text { maneuvers, pain relief with SI } \\
\text { joint block }\end{array}$} & $\begin{array}{l}10 \text { mm Hollow Modular } \\
\text { Anchorage Screw packed } \\
\text { with demineralized bone } \\
\text { matrix across the SI joint. }\end{array}$ & Blood loss: $<50 \mathrm{ml}$ & \multirow[t]{6}{*}{ None reported } \\
\hline & & Gender $11 \mathrm{~F} / 4 \mathrm{M}$ & & \multirow{5}{*}{$\begin{array}{l}\text { Post-op care: Partial weight } \\
\text { bearing for six weeks and full } \\
\text { weight bearing by } 12 \text { weeks. }\end{array}$} & LOS 2.7 days & \\
\hline & & Follow-up: 17 months & & & $\begin{array}{l}\text { SF-36 increased: PF } 37 \text { to } 80 \text {, } \\
\text { GH } 53 \text { to } 86\end{array}$ & \\
\hline & & Unilateral 11/Bilateral 4 & & & Majeed's: 37 to 79 & \\
\hline & & $\begin{array}{l}\text { Previous lumbar surgery: } \\
40 \%\end{array}$ & & & Good/Excellent: 13/15 & \\
\hline & & $\begin{array}{l}\text { Dx: Osteoarthritis (7), SI } \\
\text { joint dysfunction(4), SI } \\
\text { joint instability (3), } \\
\text { Inflammatory Arthritis (1) }\end{array}$ & & & Fusion in all patients & \\
\hline \multirow[t]{7}{*}{ Al-Khayer2008 [23] } & \multirow[t]{7}{*}{9} & Age: 42 years & $\begin{array}{l}\text { Tenderness over the sacral } \\
\text { sulcus, positive provocative } \\
\text { maneuvers, }\end{array}$ & $\begin{array}{l}10 \text { mm Hollow Modular } \\
\text { Anchorage Screw packed } \\
\text { with demineralized bone } \\
\text { matrix across the SI joint. }\end{array}$ & Blood loss: $<50 \mathrm{ml}$ & $\begin{array}{l}1 \text { deep wound } \\
\text { infection }\end{array}$ \\
\hline & & Gender: $9 \mathrm{~F}$ & \multirow{6}{*}{$\begin{array}{l}\text { X-rays to exclude other pain } \\
\text { sources, relief from SI joint } \\
\text { block }\end{array}$} & \multirow[t]{6}{*}{$\begin{array}{l}\text { Post-op care: early } \\
\text { mobilization w/in pain limits }\end{array}$} & $\begin{array}{l}\text { No screw loosening, } \\
\text { nonunion, or failure }\end{array}$ & \multirow[t]{6}{*}{$\begin{array}{l}\text { Complication rate } \\
11 \%\end{array}$} \\
\hline & & Follow-up: 40 mo & & & LOS: 6.9 days & \\
\hline & & Unilateral 6 /Bilateral 3 & & & Return to work: $4 / 9$ & \\
\hline & & $\begin{array}{l}\text { Symptom Duration: } 30 \\
\text { mo }\end{array}$ & & & ODI decreased: 59 to 45 & \\
\hline & & $\begin{array}{l}\text { Prior treatments: Failed } \\
\text { conservative treatment }\end{array}$ & & & VAS decreased: 8.1 to 4.6 & \\
\hline & & Dx: Chronic SI joint pain & & & Satisfaction: 6.8 (out of 10) & \\
\hline \multirow[t]{6}{*}{ Wise, 2008 [24] } & \multirow[t]{6}{*}{13} & Age: 53 years & \multirow[t]{6}{*}{ Relief with SI joint block } & $\begin{array}{l}9 \mathrm{~mm} \text { hole drilled through } \\
\text { the longitudinal aspect of the } \\
\text { SI joint. } 2 \text { cages packed with } \\
\text { BMP placed across the } \\
\text { anterior portion of the SI } \\
\text { joint. }\end{array}$ & Blood loss: < $100 \mathrm{ml}$ & $\begin{array}{l}\text { Reoperation } \\
\text { (nonunion): } 1\end{array}$ \\
\hline & & Gender: $12 \mathrm{~F} / 1 \mathrm{M}$ & & \multirow{5}{*}{$\begin{array}{l}\text { Post-op care: limited waist } \\
\text { bending, and a sacral belt for } \\
6 \text { mo; full activity at } 6 \text { mo }\end{array}$} & Length of stay: 1.7 days & \multirow{5}{*}{$\begin{array}{l}\text { Complication and } \\
\text { Revision rate: } 8 \%\end{array}$} \\
\hline & & Follow-up: 29.5 mo & & & Fusion rate: $89 \%$ & \\
\hline & & Unilateral 7/Bilateral 6 & & & $\begin{array}{l}\text { Low back VAS improved } 4.9 \\
\text { pts }\end{array}$ & \\
\hline & & $\begin{array}{l}\text { Previous lumbosacral } \\
\text { surgery: } 8 / 13\end{array}$ & & & Leg VAS improved 2.4 pts & \\
\hline & & $\begin{array}{l}\text { Prior treatments: Failed > } \\
6 \text { mo of conservative } \\
\text { therapy }\end{array}$ & & & & \\
\hline
\end{tabular}


Table 7 Reports of SI joint fusion (Continued)

\begin{tabular}{|c|c|c|c|c|c|c|}
\hline \multirow[t]{7}{*}{ Buchowski, 2005 [21] } & \multirow[t]{7}{*}{20} & Age: 45 years & \multirow{2}{*}{$\begin{array}{l}\text { Sacral sulcus palpation, } \\
\text { positive provocative } \\
\text { maneuvers, }\end{array}$} & Modified Smith-Petersen & Blood loss: $290 \mathrm{~mL}$ & Pseudoarthrosis: 3 \\
\hline & & Gender: 17 F/3 M & & $\begin{array}{l}\text { Incision over posterior } 2 / 3 \text { of } \\
\text { iliac crests. Graft stabilized w/ } \\
\text { plate and screws. }\end{array}$ & Solid fusion: 17 & $\begin{array}{l}\text { Deep wound } \\
\text { infection: } 2\end{array}$ \\
\hline & & Follow-up: 5.8 yrs & \multirow{5}{*}{$\begin{array}{l}\text { Pain relief with intraarticular } \\
\text { SI joint injections }\end{array}$} & \multirow{5}{*}{$\begin{array}{l}\text { Post-op care: Non-weight } \\
\text { bearing for at least } 3 \text { months. }\end{array}$} & LOS: 5.2 days & Painful hardware: 1 \\
\hline & & $\begin{array}{l}\text { Prior treatments: All failed } \\
\text { nonoperative treatment }\end{array}$ & & & Return to work: $8 / 20$ & $\begin{array}{l}\text { Revision surgery } \\
\text { (anterior): } 3\end{array}$ \\
\hline & & $\begin{array}{l}\text { Previous spine surgery: } \\
15 / 20\end{array}$ & & & $\begin{array}{l}\text { SF-36 improved (except GH \& } \\
\text { MH) }\end{array}$ & $\begin{array}{l}\text { Complication rate: } \\
30 \%\end{array}$ \\
\hline & & $\begin{array}{l}\text { Symptom Duration: } \\
2.6 \text { yrs }\end{array}$ & & & $\begin{array}{l}\text { AAOS MODEMS sig. } \\
\text { improved (except } \\
\text { Comorbidity) }\end{array}$ & Revision rate: $15 \%$ \\
\hline & & $\begin{array}{l}\text { Dx: SI joint dysfunction } \\
\text { (13), Osteoarthritis (5), } \\
\text { Spondyloarthropathy (1), } \\
\text { SI joint instability (1) }\end{array}$ & & & $\begin{array}{l}60 \% \text { would have surgery } \\
\text { again }\end{array}$ & \\
\hline \multirow[t]{5}{*}{ Giannikas, 2004 [35] } & \multirow[t]{5}{*}{5} & Age: 22 to 44 years & \multirow[t]{5}{*}{$\begin{array}{l}\text { SI joint tenderness, positive } \\
\text { provocative maneuvers, bone } \\
\text { scan, relief with SI joint block }\end{array}$} & $\begin{array}{l}\text { Two bone plugs harvested } \\
\text { from the iliac crest and } \\
\text { placed through the superior } \\
\text { and inferior aspects of the SI } \\
\text { Joint. }\end{array}$ & Complete pain relief: $4 / 5$ & None reported \\
\hline & & Gender: 3 F/2 M & & \multirow{4}{*}{$\begin{array}{l}\text { Post-op care: Non-weight } \\
\text { bearing for at least } 3 \text { months. }\end{array}$} & \multirow[t]{4}{*}{ Partial pain relief: 1/5 } & \\
\hline & & Follow-up: 29 mo & & & & \\
\hline & & $\begin{array}{l}\text { Symptom Duration: } 10 \text { to } \\
40 \text { mo }\end{array}$ & & & & \\
\hline & & $\begin{array}{l}\text { Dx: Idiopathic (1), } \\
\text { Previous trauma (4) }\end{array}$ & & & & \\
\hline \multirow[t]{4}{*}{ Moore, 1997 [20] } & \multirow[t]{4}{*}{77} & Gender: 48 F/29 M & \multirow[t]{4}{*}{ Relief with SI joint block } & $\begin{array}{l}\text { Modified Smith-Petersen } \\
\text { technique with } 15 \mathrm{~cm} \text { inci- } \\
\text { sion to reveal the ilium and } \\
\text { sacrum. Bone harvested from } \\
\text { the ilium and placed in the SI } \\
\text { joint after removing the car- } \\
\text { tilage. } 2-3 \text { cannulated screws } \\
\text { to lock graft in place. }\end{array}$ & \multirow[t]{4}{*}{ 62/77 successful (80.5\%) } & $\begin{array}{l}\text { Superficial wound } \\
\text { infection: } 1\end{array}$ \\
\hline & & Unilateral 74/Bilateral 3 & & \multirow[t]{3}{*}{$\begin{array}{l}\text { Post-op care: Non-weight } \\
\text { bearing for } 8 \text { weeks. }\end{array}$} & & $\begin{array}{l}\text { Post-op radicular pain: } \\
1\end{array}$ \\
\hline & & $\begin{array}{l}\text { Prior treatments: Failed } \\
6 \text { months of rehab } \\
\text { programs }\end{array}$ & & & & $\begin{array}{l}\text { Sciatic notch fracture: } \\
1\end{array}$ \\
\hline & & $\begin{array}{l}\text { Symptom duration: } 6 \text { to } \\
84 \text { mo }\end{array}$ & & & & Pseudoarthrosis: 7 \\
\hline
\end{tabular}

Gender: 3 F/2 M

Dx: Idiopathic (1)

Previous trauma (4)

84 mo 
Table 7 Reports of SI joint fusion (Continued)

\begin{tabular}{|c|c|c|c|c|c|c|}
\hline & & Follow-up: 1 to 5 years & & & & Complication rate: \\
\hline & & $\begin{array}{l}\text { Dx: Chronic painful } \\
\text { dysfunction }\end{array}$ & & & & \\
\hline \multirow[t]{5}{*}{ Keating, 1995 [19] } & 26 & Age: 38.3 years & \multirow[t]{5}{*}{ Relief with SI joint block } & $\begin{array}{l}\text { Inferior SI joint debrided, } \\
\text { decorticated, and packed } \\
\text { with bone graft. Secured with } \\
2 \text { lateral compression screws. }\end{array}$ & Pain decreased: 6.1 to 2.9 & \multirow[t]{5}{*}{ None reported } \\
\hline & & Follow-up: 16 weeks & & $\begin{array}{l}\text { Post-op care: } 16 \text { week } \\
\text { rehabilitation program. }\end{array}$ & $\begin{array}{l}\text { Work Status increased: } 2.3 \text { to } \\
3.3\end{array}$ & \\
\hline & & $\begin{array}{l}\text { Prior treatments: Failed } \\
6 \text { weeks of aggressive } \\
\text { rehab }\end{array}$ & & & $\begin{array}{l}5 \text { patients returned to work } \\
\text { after } 16 \text { mo of } \\
\text { unemployment }\end{array}$ & \\
\hline & & $\begin{array}{l}\text { Symptom duration: } 38.3 \\
\text { mo }\end{array}$ & & & & \\
\hline & & Dx: Chronic LBP & & & & \\
\hline \multirow[t]{6}{*}{ Waisbrod, 1987 [17] } & \multirow[t]{6}{*}{21} & Age: 42 & \multirow{6}{*}{$\begin{array}{l}\text { Tenderness over the SI joint, } \\
\text { positive provocative } \\
\text { maneuvers, pain provocation } \\
\text { w/ NaCL injection, relief w/ SI } \\
\text { joint block }\end{array}$} & $\begin{array}{l}\text { SI joint excised and packed } \\
\text { W/ iliac crest bone graft and } \\
\text { ceramic blocks. }\end{array}$ & \multirow[t]{6}{*}{ 11/21 Satisfactory results } & Pseudoarthrosis: 2 \\
\hline & & Gender: $18 \mathrm{~F} / 3 \mathrm{M}$ & & \multirow{5}{*}{$\begin{array}{l}\text { Post-op care: Spica cast for } \\
8 \text { weeks. }\end{array}$} & & Infection: 1 \\
\hline & & Follow-up: 30 mo & & & & \multirow{4}{*}{$\begin{array}{l}\text { Complication rate: } \\
14 \%\end{array}$} \\
\hline & & $\begin{array}{l}\text { Previous spine surgery: } 7 / \\
21\end{array}$ & & & & \\
\hline & & $\begin{array}{l}\text { Symptom duration: > } \\
2 \text { years }\end{array}$ & & & & \\
\hline & & Dx: SI joint pain & & & & \\
\hline
\end{tabular}


even been denied by IRBs, who contend that the benefits of MIS surgery (typically shorter operating time, less blood loss and shorter hospital stay) make it unethical to subject patients to randomization [40].

This study is also not concurrent. Most surgeons interviewed during the site identification process performed either open or MIS SI joint procedures, but not both. In an incidence rate study of data obtained from the AMA/ Specialty Society Relative Value Scale Update Committee (RUC) database, less than 200 open SI joint fusion procedures were performed annually between 2001 and 2008 [41]. In 2012, 85\% of all SI joint fusions performed were minimally invasive. It is apparent that the open surgical technique has fallen out of favor with the introduction of MIS methods.

Whether our results are reflective of the entire population of patients who undergo open or MIS fusion is not known. The low rate of open SI joint fusions performed annually coupled with the rapid adoption of MIS techniques with favorable safety and effectiveness profiles makes a prospective randomized controlled trial highly unlikely.

The current study also lacks patient-reported outcomes typically collected in controlled trials, such as Oswestry Disability Index and SF-12 or SF-36. These outcomes instruments are labor intensive for both patients as well as office staff, hence surgeons in private practice do not typically collect them. Not all sites had complete data sets to include EBL, surgical operating time and length of stay for every patient. Finally, pain rating questionnaires, included as part of each surgeon's standard practice, may have varied in content and been administered differently across sites.

\section{Conclusion}

Minimally invasive SI joint fusion using a series of triangular, titanium, TPS coated implants (iFuse Implant System) results in more favorable perioperative measures, fewer reoperations and significantly improved clinical outcomes compared to traditional open surgical SI joint arthrodesis.

\section{Competing interests}

RC and DC are employees of SI-BONE, Inc. AGS, LR, DS, MG and NS are paid consultants of SI-BONE, Inc. LR and NS are stockholders in SI-BONE, Inc. JK, MM have no competing interests.

\section{Authors' contributions}

$A G S, L R, D S, M G, J K, M M, N S$ performed patient surgeries, and contributed to manuscript draft. RC and DC drafted manuscript, performed data analysis and interpretation. All authors reviewed and provided final approval of manuscript.

\section{Acknowledgements}

The authors thank Chris Barker, PhD, who performed statistical modeling.

\section{Author details}

${ }^{1} J a c k v i l l e$, FL, USA. ${ }^{2}$ SI-BONE, Inc., 3055 Olin Ave, Suite 2200, San Jose, CA, USA. ${ }^{3}$ Alice Peck Day Memorial Hospital, 129 Mascoma Street, Lebanon, NH 03766, USA. ${ }^{4}$ Center for Spinal Stenosis and Neurologic Care, PO Box 8815, Lakeland, FL 33806, USA. '5razos Spine, 1602 Rock Prarie Road, East Tower, Suite 2400, College Station, TX 77845, USA. ${ }^{6}$ Medical Center of Aurora, Spine Center of Innovation, Suite 210, 1400 S Potomac St, Aurora, CO 80012, USA. ${ }^{7}$ The Spine Clinic, 7925 Youree Drive, Suite 200, Shreveport, LA 71115, USA. ${ }^{8}$ UCLA Spine Center, 1131 Wilshire Blvd, Suite 100, Santa Monica, CA 90401, USA.

Received: 25 September 2013 Accepted: 28 October 2013

Published: 30 October 2013

\section{References}

1. Foley BS, Buschbacher RM: Sacroiliac joint pain: anatomy, biomechanics, diagnosis, and treatment. Am J Phys Med Rehabil 2006, 85(12):997-1006.

2. Schwarzer $A C$, Aprill CN, Bogduk N: The sacroiliac joint in chronic low back pain. Spine 1995, 20(1):31-37.

3. Weksler N, Velan GJ, Semionov M, Gurevitch B, Klein M, Rozentsveig V, et al: The role of sacroiliac joint dysfunction in the genesis of low back pain: the obvious is not always right. Arch Orthop Trauma Surg 2007, 127(10):885-888

4. Sembrano JN, Polly DW: How often is low back pain not coming from the back? Spine 2009, 34(1):E27-E32.

5. Maigne JY, Aivaliklis A, Pfefer F: Results of sacroiliac joint double block and value of sacroiliac pain provocation tests in 54 patients with low back pain. Spine 1996, 21(16):1889-1892.

6. Bernard TN, Kirkaldy-Willis WH: Recognizing specific characteristics of nonspecific low back pain. Clin Orthop Relat Res 1987, 217:266-280.

7. Slinkard N, Agel J, Swiontkowski MF: Documentation of outcomes for sacroiliac joint fusion: does prior spinal fusion influence the outcome? Eur Spine J 2013. epub ahead of print.

8. Liliang P-C, Lu K, Liang C-L, Tsai Y-D, Wang K-W, Chen H-J: Sacroiliac joint pain after lumbar and lumbosacral fusion: findings using dual sacroiliac joint blocks. Pain Med 2011, 12(4):565-570.

9. DePalma MJ, Ketchum JM, Saullo TR: Etiology of chronic Low back pain in patients having undergone lumbar fusion. Pain Med 2011, 12(5):732-739.

10. Ha K-Y, Lee J-S, Kim K-W: Degeneration of sacroiliac joint after instrumented lumbar or lumbosacral fusion: a prospective cohort study over five-year follow-up. Spine 2008, 33(11):1192-1198.

11. Szadek KM, van der Wurff $P$, van Tulder MW, Zuurmond WW, Perez RSGM: Diagnostic validity of criteria for sacroiliac joint pain: a systematic review. J Pain 2009, 10(4):354-368.

12. Simopoulos TT, Manchikanti L, Singh V, Gupta S, Hameed H, Diwan S, et al: A systematic evaluation of prevalence and diagnostic accuracy of sacroiliac joint interventions. Pain Physician 2012, 15(3):E305-E344.

13. Gaenslen FJ: Sacro-iliac arthrodesis: indications, author's technic and endresults. JAMA 1927, 89(24):2031-2035.

14. Robinson HS, Brox Jl, Robinson R, Bjelland E, Solem S, Telje T: The reliability of selected motion- and pain provocation tests for the sacroiliac joint. Man Ther 2007, 12(1):72-79.

15. Cohen SP, Hurley RW, Buckenmaier CC, Kurihara C, Morlando B, Dragovich A: Randomized placebo-controlled study evaluating lateral branch radiofrequency denervation for sacroiliac joint pain. Anesthesiology 2008, 109(2):279-288.

16. Smith-Petersen MN: Arthrodesis of the sacroiliac joint. A new method of approach. J Bone Joint Surg Am 1921, 3(8):400-405.

17. Waisbrod H, Krainick JU, Gerbershagen HU: Sacroiliac joint arthrodesis for chronic lower back pain. Arch Orthop Trauma Surg 1987, 106(4):238-240.

18. Rand JA: Anterior sacro-iliac arthrodesis for post-traumatic sacro-iliac arthritis. A case report. J Bone Joint Surg Am 1985, 67(1):157-159.

19. Keating J, Sims V, Avillar M: Sacroiliac joint fusion in a chronic low back pain population. In The Integrated Function of the Lumbar Spine and Sacroiliac Joint. Edited by Vleeming A. Rotterdam: Churchill Livingston; 1995:361-365.

20. Moore MR: Surgical treatment of chronic painful sacroiliac joint dysfunction. In Movement, stability, and low back pain: the essential role of the pelvis. New York: Churchill Livingstone; 1997:563-572.

21. Buchowski JM, Kebaish KM, Sinkov V, Cohen DB, Sieber AN, Kostuik JP: Functional and radiographic outcome of sacroiliac arthrodesis for the disorders of the sacroiliac joint. Spine J 2005, 5(5):520-528. 
22. Khurana A, Guha AR, Mohanty K, Ahuja S: Percutaneous fusion of the sacroiliac joint with hollow modular anchorage screws: clinical and radiological outcome. J Bone Joint Surg Br 2009, 91(5):627-631.

23. Al-Khayer A, Hegarty J, Hahn D, Grevitt MP: Percutaneous sacroiliac joint arthrodesis: a novel technique. J Spinal Disord Tech 2008, 21(5):359-363.

24. Wise $C L$, Dall BE: Minimally invasive sacroiliac arthrodesis: outcomes of a new technique. J Spinal Disord Tech 2008, 21(8):579-584.

25. Sachs D, Capobianco R: One year successful outcomes for novel sacroiliac joint arthrodesis system. Ann Surg Innov Res 2012, 6(1):13.

26. Sachs D, Capobianco R: Minimally invasive sacroiliac joint fusion: one-year outcomes in 40 patients. Adv Orthop 2013, 2013:536128.

27. Rudolf L: Sacroiliac joint arthrodesis-MIS technique with titanium implants: report of the first 50 patients and outcomes. Open Orthop J 2012, 6(1):495-502.

28. Rudolf $\mathrm{L}$ : MIS fusion of the $\mathrm{SI}$ joint: does prior lumbar spinal fusion affect patient outcomes? Open Orthop J 2013, 7:163-168.

29. Cummings J Jr, Capobianco RA: Minimally invasive sacroiliac joint fusion: one-year outcomes in 18 patients. Ann Surg Innov Res 2013, 7(1):12.

30. The international society for the advancement of spinal surgery. http:// www.isass.org/public_policy/2013-08-07-isass-statement-minimally-invasivesi-joint-fusion-coding-changes.html]

31. Laslett M: Evidence-based diagnosis and treatment of the painful sacroiliac joint. J Man Manip Ther 2008, 16(3):142-152.

32. Copay AG, Glassman SD, Subach BR, Berven S, Schuler TC, Carreon LY: Minimum clinically important difference in lumbar spine surgery patients: a choice of methods using the Oswestry Disability Index, Medical Outcomes Study questionnaire Short Form 36, and pain scales. Spine J 2008, 8(6):968-974.

33. Glassman SD, Copay AG, Berven SH, Polly DW, Subach BR, Carreon LY: Defining substantial clinical benefit following lumbar spine arthrodesis. J Bone Joint Surg Am 2008, 90(9):1839-1847.

34. Kibsgård TJ, Røise O, Sudmann E, Stuge B: Pelvic joint fusions in patients with chronic pelvic girdle pain: a 23-year follow-up. Eur Spine J 2012, 22(4):871-877.

35. Giannikas KA, Khan AM, Karski MT, Maxwell HA: Sacroiliac joint fusion for chronic pain: a simple technique avoiding the use of metalwork. Eur Spine J 2004, 13(3):253-256.

36. Mason LW, Chopra I, Mohanty K: The percutaneous stabilisation of the sacroiliac joint with hollow modular anchorage screws: a prospective outcome study. Eur Spine J 2013. epub ahead of print.

37. Pull Ter Gunne AF, van Laarhoven CJHM, Hosman AJF, van Middendorp JJ: Surgical infections. J Neurosurg Spine 2013, 18(6):661-662.

38. Kurmann A, Vorburger SA, Candinas D, Beldi G: Operation time and body mass index are significant risk factors for surgical site infection in laparoscopic sigmoid resection: a multicenter study. Surg Endosc 2011 25(11):3531-3534

39. Skråmm I, Saltyte Benth J, Bukholm G: Decreasing time trend in SSI incidence for orthopaedic procedures: surveillance matters! J Hosp Infect 2012, 82(4):243-247.

40. McAfee PC, Phillips FM, Andersson G, Buvenenadran A, Kim CW, Lauryssen C, et al: Minimally Invasive Spine Surgery. Spine 2010, 35:S271-S273.

41. Ackerman SJ, Polly DW, Eunyoung K, Knight T: What is the Frequency of Minimally Invasive Sacroiliac Joint Fusion Annually in the United States? In Proceedings of the $8^{\text {Th }}$ Interdisciplinary World Congress on Low Back and Pelvic Pain. Dubai, U.A.E: Dubai; 2013.

\section{doi:10.1186/1750-1164-7-14}

Cite this article as: Smith et al:: Open versus minimally invasive sacroiliac joint fusion: a multi-center comparison of perioperative measures and clinical outcomes. Annals of Surgical Innovation and Research 2013 7:14.

\section{Submit your next manuscript to BioMed Central and take full advantage of:}

- Convenient online submission

- Thorough peer review

- No space constraints or color figure charges

- Immediate publication on acceptance

- Inclusion in PubMed, CAS, Scopus and Google Scholar

- Research which is freely available for redistribution

Submit your manuscript at www.biomedcentral.com/submit 